\title{
Joanna Sycz-Opoń
}

University of Silesia

\section{Ksenia Gałuskina}

University of Silesia

\section{MACHINE TRANSLATION IN THE HANDS OF TRAINEE TRANSLATORS - AN EMPIRICAL STUDY}

\begin{abstract}
Automated translation (machine translation, MT) is systematically gaining popularity among professional translators, who claim that editing MT output requires less time and effort than translating from scratch. MT technology is also offered in leading translator's workstations, e.g., SDL Trados Studio, memoQ, Déjà Vu and Wordfast. Therefore, the dilemma arises: should MT be introduced into formal translation training? In order to answer this question, first, it is necessary to understand how trainee translators actually use MT.

This study is an attempt to obtain this knowledge. The methodology applied in this investigation is text analysis. During the experiment sessions the students were asked to translate a legal text using MT tools, which in practice meant the post-editing of the MT raw output. The post-edited versions of the text underwent analysis in order to answer the following research questions:

- What are the most typical errors contained in both French and English MT output?

- How critical are the students towards the text generated by MT?

- How perceptive are the students during the post-editing task?

- Are they able to detect and correct errors using their knowledge and skills? The results of this study suggest that the post-editing of the MT raw output is as demanding for translation students as traditional translation, however, it requires a different set of skills, such as critical thinking and perceptiveness. Therefore, a special kind of training related to the effective use of MT technology should be implemented during translation classes.
\end{abstract}

Keywords: post-editing, translation training, machine translation.

\section{Introduction}

Since its invention in the mid-twentieth century, machine translation (MT) has been systematically gaining popularity, not only among those who need it for basic communication, but also among profession- 
als. As Hutchins (2007) reports, for many years MT solutions have been successfully utilized by large companies, such as Xerox, Ford, General Motors, and institutions, e.g., the European Commission and the Pan American Health Organization, which thanks to MT technology have been able to translate considerable volumes of text quickly and cost-effectively. Yet more importantly, MT has also caught the attention of freelance translators and translation agencies. There are not many studies that report the actual number of translators using MT technology, but the ones that are available indicate interest in what MT has to offer. The report by Fulford \& Granell-Zafra (2004) states that 3\% of the 390 interviewed translators utilize MT in their work, and the report by Fulford (2002) shows that $26 \%$ of freelancers from the UK admit the use of MT from time to time. As a response to growing interest, in the last decade MT has been added to many translators' workstations, e.g., SDL Trados Studio, memoQ, Déjà $V u$ and Wordfast. Thus, now MT technology is easily accessible if one desires to use it. The change of heart about MT is not dramatic. There are still many unconvinced professionals who prefer their old ways of translating texts. The general trend, however, is that the embrace of automated translation is becoming stronger and wider in professional circles.

Taking the above into consideration, it seems unreasonable to ignore MT technology during translation classes. Automated translation is one of the tools that may prove useful in students' future work. However, as many would claim, the introduction of MT into formal translation training is potentially risky. Typically work with the assistance of MT involves the post-editing of the text generated by the machine (the so-called raw output) until it is of publishable quality. This is a task significantly different than traditional translation. The ISO 17100:2015 Translation Services Standard, which regulates good practices in the translation industry, states that "the use of raw output from machine translation plus post-editing is outside the scope of this International Standard." The character of work with MT was summarized by Sycz-Opoń (2015) as follows:

On the one hand, MT assistance releases translators from the excessive use of memory and typewriting.... On the other hand, cooperation with MT demands critical thinking, perceptiveness and most of all flexibility.

Moreover, it could be assumed that MT is handled differently by professionals and by the trainees who are still learning the craft of translation. While it may prove useful in professional practice, in the hands of trainee translators the use of automated translation may sabotage the learning 
process, at least when introduced into the classroom without due preparation.

This research project aims to discover how trainee translators actually use MT during the translation of a specialist text: what problems they encounter and what mistakes they make. The results of this study should help teachers make the decision whether to integrate MT into translation training, and can offer practical advice on how to do it with the maximum benefit for the students.

\section{Methodology}

This paper presents the initial stage of a large-scale project into the students' use of MT technology. The methodology applied in this study combines three methods: (1) text analysis (2) observation of the post-editing process and (3) a questionnaire. This paper presents the results of the first stage of the research, i.e. text analysis.

The students participating in the study were asked to conduct translation with the assistance of Google $M T$ tool, which in practice meant the post-editing of the raw output generated by the machine. During their work the participants were allowed to use the Internet as well as printed sources of information. The experiment session was recorded via a screen-recording programme. The direction of translation was from L1 (Polish) to L2 (English or French); thus it involved reception of the text in the native language and production of the text in the foreign language. Two types of specialist texts were translated during the experiment sessions:

1. A descriptive specialist text devoted to legal matters related to marriage (see Appendix 1).

2. A business text devoted to the general presentation of a company, which constitutes part of a company's Annual Report (see Appendix 2).

Prior to the experiment, during translation classes, the participants had gained theoretical knowledge of the subject matters discussed in the aforementioned specialist texts, i.e. family law and company law.

The subjects participating in the experiment were students of English and French, attending translation courses offered by the Institute of English and the Institute of Romance Languages and Translation Studies at the University of Silesia. It was decided that the participants should constitute a heterogeneous group. Thus, they were characterized by varying levels of foreign language fluency (from B1 to $\mathrm{C} 2$ ), varied translation experience (having completed from 30 to 150 hours of translation classes) and varying 
knowledge of business and law. Once the translation task was completed, the participants were asked to fill in an online questionnaire, the results of which will be presented in a separate publication.

The text analysis was conducted with the assistance of an automatic comparison tool offered by the Word Processor programme. It compares the raw text generated by MT and its post-edited version. In this way one obtains a clear view of all corrections done to the original text, as illustrated by Example 1.

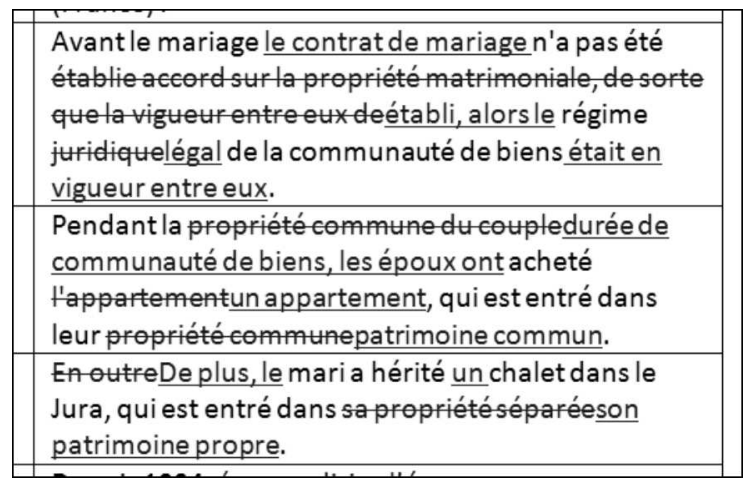

Example 1. An excerpt of the text generated by the Word Processor comparison tool

The analysis consisted of two stages, which match two cognitive processes occurring during a post-editing task:

- The detection phase, in which the participants read the MT raw output to detect any errors that require correction

- The correction phase, in which the participants correct the errors using available sources of information and their own knowledge

\section{The detection phase}

During the analysis of the detection phase, we looked closely at what types of errors contained in the MT raw output were the subjects of correction and with what frequency. For the sake of analysis we singled out three categories of errors:

- Grammatical

- Lexico-semantic

- Syntactic 
The category grammatical embraces the following types of errors:

- a misspelled word

- an incorrect accent (French)

- an incorrect elision or no elision

- an incorrect word formation

- a wrong tense

- the use of the wrong category of a word (e.g., a noun used instead of a verb)

- an incorrect pronoun (wrong, absent, unnecessary or doubled)

- incorrect word capitalisation

- an incorrect article or no article

- a missing negative particle

- incorrect agreement

The category syntactic includes the following errors:

- wrong sentence order

- an incorrect conjunction

- wrong punctuation

The category lexico-semantic includes errors related to lexis, such as:

- mistranslation of a lexical item

- no translation (a word or phrase left in the original language)

- lack of translator's remark where necessary

Lexical items are understood as:

- single lexical items (noun, verb, adjective, adverb, preposition)

- multiple lexical items (set phrases, collocations, multi-word terms)

- abbreviations

\section{Results: errors in MT output}

Figures 1 and 2 present the frequencies of the aforementioned error categories: grammatical, lexico-semantic and syntactic. The overwhelming majority of errors detected in the English output are related to the lexicosemantic aspects of the text (78\% of the total). Syntactic errors constitute $13 \%$ and grammatical $9 \%$ of the total number of errors discovered by the participants. The proportion of errors in the French MT output is noticeably different. The majority of errors pertain to the grammatical (42\%) and lexico-semantic $(38 \%)$ aspects of the text, and syntactic errors constitute $20 \%$ of total errors discovered in the MT output. 


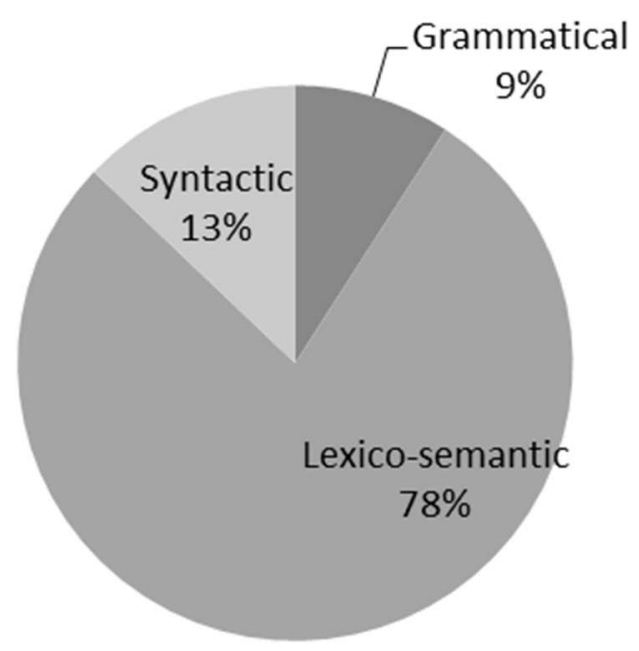

Figure 1. Errors in the English MT output

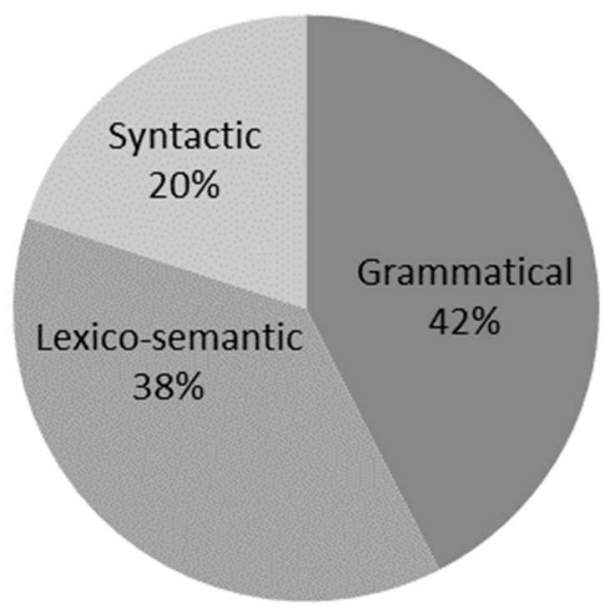

Figure 2. Errors in the French MT output

\section{Grammatical errors}

As was to be expected, the analysis revealed significant differences regarding the quality of the English and French MT output (42\% of grammatical errors in the French output versus $9 \%$ in the English output). French proved to be less MT-friendly, because of its grammatical attributes (inflection). It is also less commonly-translated than English, which has a direct impact on MT quality. Due to the fact that contemporary MT systems, including Google, utilize the corpora of past translations, the more widespread 
the language the better the MT quality (Hutchins, 2008). Below are the examples of the typical errors contained in the French and English output (Examples 2, 3, 4 and 5).

$$
\begin{aligned}
& \text { En outre le mari a hérité d’un chalet dans le } \\
& \text { Jura, qui est entré dans sa propriété séparée. }
\end{aligned}
$$

Example 2. An incorrect article and a missing article

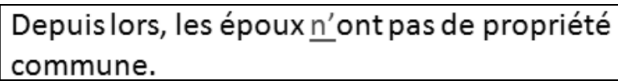

Example 3. A negative particle missing

Pierre et Marguerite ont deux enfants: Alan, né le 30 Mars 1985. Et Ivonne, néelle 3 mai 1987.

Example 4. Incorrect agreement (male past participle instead of female)

PK S.A... as a producer commercial company
since 1996, has been exporting coke exports and protect
supplying the key Polish coking plants in coking coal since
1996. It is the largest company peddling coke in the world

Example 5. Wrong tense (Present Simple instead of Present Perfect)

\section{Syntactic errors}

Since the quality of MT performance is systematically getting better, the frequency of syntactic errors is not as high as it was just a few years ago (Graham, Baldwin, Moffat, \& Zobel, 2014). During post-edition the syntactic errors were easily spotted by the participants, because they usually made the sentence illogical for the readers. Yet the participants experienced difficulty diagnosing what element of the sentence was the actual source of a problem and how to repair the fault. The typical syntactic errors were calques of the original word order, as illustrated by Examples 6,7 and 8 .

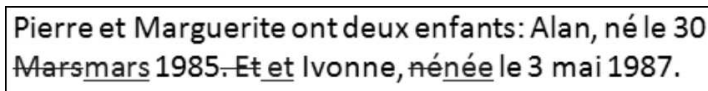

Example 6. Wrong punctuation (unnecessary full stop) 


The company offers professional eommercial-service by a young,
specialized staff employees who already have many years of experience and
business contacts in international trade, actively participates in enferences
and-scientific - technical and commercial conferences in the country and in the

Example 7. Wrong word order (calque), plus the wrong use of the article "a", wrong word inflation ("participates") and a lexical error ("staff emplyees")

\section{Lexico-semantic errors}

Lexico-semantic errors often involved the lack of necessary translators' remarks (Examples 8 and 9), a wrong date (Example 13), an incorrect proper name (Example 14), non-translation of a fragment of the text (Example 10), translation of a lexical item that should remain untranslated (Example 11) and an erroneous equivalent of a term or phrase (Example 12). Occasionally, there appeared errors related to the wrong rendition of a term of art. They were however not easily detectable by the participants, and some of them remained uncorrected.

\section{PK S.A. [joint-stock company] as a producer commercial company}

Example 8. A translator's remark missing

\section{In the "Rzeczpospolita" [Polish daily newspaper]}

Example 9. A translator's remark missing, plus the unnecessary of the article "the" In the period from 01.01.2000 until 21.08.2000,
the composition of the Management Board of the Company
was astępującyas follows:

Example 10. The missing translation of the word "następujący" because of a spelling error in the original text

$$
\begin{aligned}
& 1 \text { GENERAL INFORMATION } \\
& X X \text { Ltd.SP. } z \text { o.n (the Company ") was }
\end{aligned}
$$

Example 11. The unnecessary translation of the incongruent term "sp. z o.o."

eontrat de mariage,en établissant unsystème
biena.

Example 12. The mistranslation of the multi-word term "ustrój rodzielności majątkowej" 


\section{The correction phase}

During the analysis of the correction phase we looked at corrections done to the texts generated by the machine. To evaluate the post-editing skills of the participants, we analysed the text in search of:

- necessary corrections - when the MT raw output contains an error and it is properly corrected

- unnecessary corrections - when the MT raw output is corrected even though it is an acceptable rendition of the original meaning

- omitted corrections - when the MT raw output contains an error, yet it is not corrected by the participant

- erroneous corrections - when the participant's correction of the MT raw output contains an error

The above data were used to answer the following research questions:

- How critical are the students towards the contents of the MT raw output?

- Are the students able to recognise the errors contained in the MT output?

- How perceptive are the students during the post-editing task?

- Are they able to correct the errors using their knowledge and skills?

\section{Results}

Figures 3 and 4 present the frequencies of the aforementioned categories of corrections. Despite the fact that the quality of the French and English MT output differed, the percentage figures related to the participants' postediting skills are very similar.

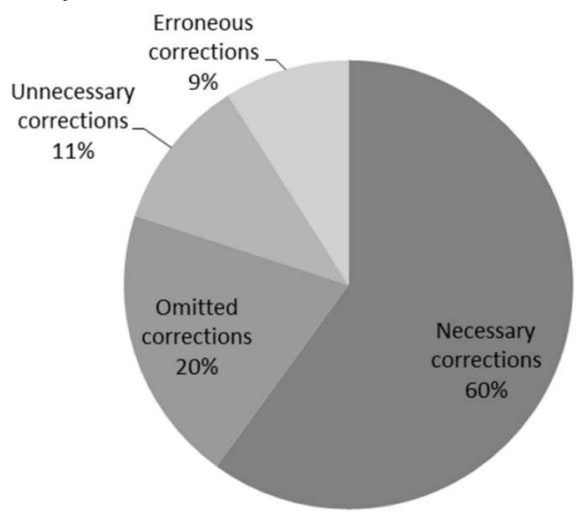

Figure 3. Corrections of the French MT output 


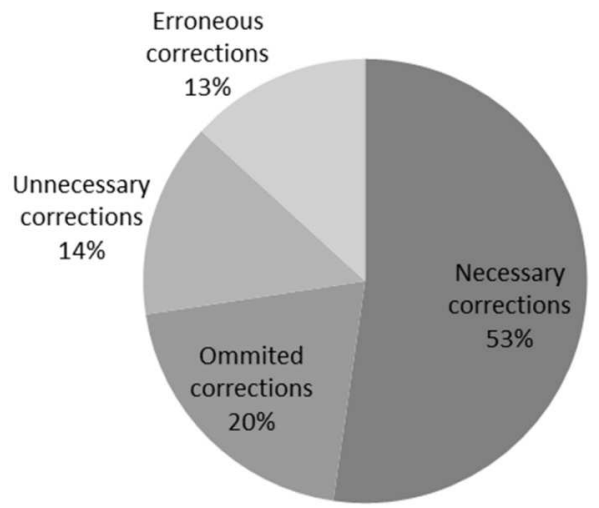

Figure 4. Corrections of the English MT output

\section{Necessary corrections}

The majority of participants' corrections of MT output were assessed as necessary. They constituted $53 \%$ of total English and $60 \%$ of total French corrections. This category includes mostly corrections of easily recognizable errors, such as wrong date, name, term of art, grammar and style (see: Examples 13, 14, 15).

\section{from 01.01-January 1, 2000 untilto August 21-08-2000,}

Example 13. Correction of a date format

\section{$\square$ JesephJózef Mielnikiewicz - President,}

Example 14. Unnecessary translation of a proper name

Depuis lors, les époux ntont pas de ropriété

communepatrimoine commun.

Example 15. Correction of a missing negative particle and a wrong term of art

\section{Omitted corrections}

Omitted corrections represented $20 \%$ of the total, both for French and English. The analysis of the post-edited texts revealed that the participants lacked perceptiveness and knowledge necessary to discover all errors present in MT output. The typical scenario was that they focused their entire attention on correcting an error discovered by them, and failed to notice another 
one located in the same fragment of the text, as illustrated by Examples 16 and 17 .

$$
0.88 \% \text {, which means that each } 1.000 \text {, - zlPLN assets gives }
$$

Example 16. The participant changed the format of currencies, but left the grammatical error uncorrected

coking plants in coking coal. It is the largest company in the world peddling coke

Example 17. Peddle, a word that has a negative connotation, not implied in the original text, was not replaced by a neutral lexeme, e.g., trade

\section{Unnecessary corrections}

Unnecessary corrections constituted $14 \%$ of total English corrections and $11 \%$ of total French corrections. The tendency to "over-correct" the text can be attributed to a lack of specialist knowledge on the part of the participants and their limited experience with specialist texts. Being trainee translators they knew only a small number of translation solutions (e.g., only one equivalent of a particular term) and perceived any other rendition of the original text as erroneous. They often replaced an acceptable equivalent with the one they knew well and were sure was correct (see Example 18 and 19).

\section{SHAREHOLDNGG}

\section{SHAREHOLDERS STRUCTURE}

Example 18. Substitution of the acceptable lexical item "shareholding" by a synonymous phrase

\section{INTRODUCTION TO THE FINANCIAL STATEMENTSSTATEMENT}

Example 19. Substitution of the lexical item "statements" by its singular form (in fact the plural form is more often used in this context than the singular)

\section{Erroneous corrections}

Erroneous corrections constituted 13\% of total English and 9\% of total French corrections. The post-editing errors resulted not only from a lack of necessary knowledge and experience, but also from insufficient focus on 
the text (see: Examples 20 to 23). They suggest that the participants were overwhelmed by the amount of information they were exposed to during the post-editing task. The participants had to analyse and assess the text produced by the MT, and detect and classify the errors contained in the MT output, which were related to the numerous layers of the text: semantic, grammatical, stylistic, etc. Then they had to correct the errors, which often meant the production of new phrases or even full sentences. At this stage of post-editing, it occurred that they would correct an error produced by the MT, but at the same time inadvertently add another one to the text. Focused on the analysis of the MT output they probably paid insufficient attention to the text they produced themselves.

PK S.A. as a producer commercial company since 1996 eoke-exports coke and protectprotects key Polish coking plants in coking coal. It is the largest company in the world peddling coke

Example 20. The participant attempted to correct a grammatical error (by adding ' $\mathrm{s}$ '), but did not realise that the proper tense in this sentence is not Present Simple but Present Perfect. The participant did not detect another important error: the word "protect" should be replaced by "supply"

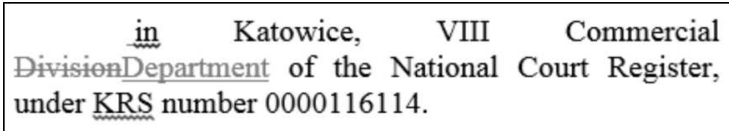

Example 21. The participant unnecessarily corrected the term "division", which is an established equivalent of the Polish term "wydział"

\section{The financial statementsstatement have been prepared on a going concern}

Example 22. The participant changed the plural form of a noun into singular, but failed to change the form of a verb "have" accordingly

The Company's asset structure is typical of afor trading company. The Company's assets is almost entirely composed of ingredients assets, mainly dominated by shortterm receivables.

Example 23. The participant used the wrong form of a verb: "is" instead of "are" 


\section{Conclusions}

It is still too early to formulate final judgements, yet the results of this part of the study suggest that for an average translation student the post-editing of the MT output is as demanding as traditional translation. The analysis revealed that final versions of the texts post-edited by the participants contained numerous errors, some of them made by the MT and not corrected by the participants, and some committed by the participants themselves. Thus, the use of MT does not seem to dramatically improve students' performance and definitely does not reduce the translation process to an easy, automatized exercise. Quite the contrary. It appears that the process of post-editing of the MT output requires the same amount of knowledge and cognitive skills as traditional translation, if not more.

The participants had serious problems with a critical evaluation of the MT output. They corrected lexical items that did not require correction (11\% unnecessary corrections of the French MT output and 14\% of English), yet they did not provide correction where it was necessary $(20 \%$ omitted corrections for both French and English).

The majority of participants did not post-edit the text to the level of satisfactory quality. They were not willing to make significant changes to the MT output; thus the text after their post-editing was still far from perfect. Though they eliminated the most striking errors, they did not manage to eliminate the stylistic awkwardness of the text. They failed to detect many errors contained in the MT output and left them uncorrected, presumably because the errors committed by the machine, e.g., wrong names or dates, do not resemble the errors that are typically made by a human translator. Another explanation for the high rate of omission errors is the fact that the assistance of MT seems to distract the participants. They are provided with a large amount of data to process, and seem to be overloaded by the task.

This is still the initial stage of our project. We plan to obtain more data from recordings and questionnaires, which will provide a broader view of the process of MT post-editing. However, at this stage we already see one practical idea that can be implemented in translation classes. As mentioned above, the main problem for the participants was the identification of all errors in the MT output. A tool that can help to develop this skill may be a special MT Evaluation Protocol (see Appendix 3). 
Fulford, H. 2002. 'Freelance translators and machine translation: an investigation of perceptions, uptake, experience and training needs'. In Proc. 6th EAMT Workshop (117-122).

Fulford, H., and Granell-Zafra, J. 2004. 'The freelance translator's workstation: An empirical investigation'. In Proceedings of 9th European Association for Machine Translation Workshop (53-61). Retrieved from http://www.mtarchive.info/EAMT-2004-Fulford.pdf

Graham, Y., Baldwin, T., Moffat, A., and Zobel, J. 2014. 'Is Machine Translation Getting Better over Time?' In Proceedings of the 14th Conference of the European Chapter of the Association for Computational Linguistics (EACL 2014). Gothenburg, Sweden.

Hutchins, J. 2007. 'Machine translation: A concise history'. Computer Aided Translation: Theory and Practice. Retrieved from http://www.hutchinsweb.me.uk /CUHK-2006.pdf

Hutchins, J. 2008. Recent developments in the use and application of machine translation. Retrieved from http://www.hutchinsweb.me.uk/OUP-2008.pdf

Sycz-Opoń, J. 2014. 'Machine Translation - Can It Assist in Professional Translation of Contracts?' Comparative Legilinguistics - International Journal for Legal Communication, 20, 81-100.

ISO 17100:2015. Translation services - Requirements for translation services.

\section{Appendix 1.}

\section{Descriptive specialist text devoted to legal matters related to marriage prepared for the purposes of the study}

\section{Historia pewnego małżeństwa}

Pierre Brown, urodzony 15 marca 1960 r. w Londynie (Wielka Brytania) oraz Marguerite Croix-Rouge, urodzona 29 września 1960 r. w Lozannie (Szwajcaria), zawarli związek małżeński 18 czerwca 1984 r. w Urzędzie Stanu Cywilnego w Nanterre (Francja). Przed ślubem nie sporządzono umowy majątkowej małżeńskiej, więc obowiązywał między nimi ustrój ustawowy wspólności majątkowej. W trakcie trwania wspólności majątkowej małżonkowie nabyli mieszkanie, które weszło do ich majątku wspólnego. Dodatkowo mąż odziedziczył domek letniskowy w Jurze, który wszedł do jego majątku odrębnego.

Od 1994 r. żona prowadzi działalność gospodarczą (kwiaciarnię), więc małżonkowie podjęli decyzję o zmianie ustroju majątkowego. Zmiana ta podyktowana była dobrem rodziny oraz ochroną majątku rodziny na przyszłość. 18 grudnia $1994 \mathrm{r}$. 
małżonkowie zawarli przed notariuszem Brunonem Dupont, notariuszem w Nanterre (Francja), umowę majątkową małżeńską, ustanawiającą ustrój rozdzielności majątkowej. Od tego czasu małżonkowie nie mają majątku wspólnego.

Pierre i Marguerite mają dwójkę dzieci: Alana, urodzonego 30 marca 1985 r. oraz Ivonne, urodzoną 3 maja 1987 r. Dzisiaj ich dzieci są już dorosłe i mają swoje własne życie. Pierre i Marguerite są zgodnym małżeństwem i rozsądnymi ludźmi, więc gdy przejdą na emeryturę planują zmienić ustrój majątkowy na rozszerzoną wspólność majątkową, co pozwoli na zabezpieczenie interesów pozostałego małżonka po śmierci jednego z nich.

\section{Appendix 2.}

\section{Raport Roczny: Polski Koks. 2009}

Available online: https://www.polskikoks.pl/firma/raporty/

(data such as names and dates changed in the document)

\section{WSTĘP}

PK S.A. jako producencka spółka handlowa od 1996 roku eksportuje koks i zabezpiecza kluczowe polskie koksownie w węgiel koksowy. Jest największą firmą handlującą koksem w świecie i posiada markę rozpoznawalną na wszystkich kontynentach.

Wzajemne współdziałanie z JSW i koksowniami daje możliwość wypracowania jednolitej, wspólnej strategii handlowej na rynku krajowym i rynkach eksportowych, osiągając maksymalne ceny eksportowe koksu zarówno w okresie dekoniunktury, jak i hossy rynkowej, przy gwarancji zabezpieczania dostaw węgla.

Rok 2000 był kolejnym rokiem, w którym Spółka odnotowała korzystne wyniki zarówno w odniesieniu do obrotów handlowych, jak i wskaźników finansowych, dbając o zaspokajanie w maksymalnym stopniu potrzeb i oczekiwań wszystkich Klientów.

Spółka oferuje profesjonalną obsługę handlową przez młodą, wyspecjalizowaną kadrę pracowników posiadających już wieloletnie doświadczenia i kontakty biznesowe w obrocie międzynarodowym, aktywnie uczestniczy w konferencjach naukowo - technicznych i handlowych w kraju i na świecie, opracowuje analizy rynkowe $\mathrm{w}$ zakresie stali, węgla i koksu, publikuje swoje opracowania w periodykach branżowych.

Dbałość o Klienta jest dla nas inspiracją do ciągłego podnoszenia jakości świadczonych usług, a wdrożony i ciągle doskonalony pod kątem skuteczności System Zarządzania Jakością zgodny z wymaganiami normy ISO 9001:2000 jest wyznacznikiem w kreowaniu pozytywnego i przyjaznego wizerunku naszej Spółki.

W rankingu 500 największych firm „Rzeczpospolitej” za rok 2000, przy przychodach netto ze sprzedaży ponad 4,1 mld zł, PK S.A. uzyskał 40 miejsce, a wśród największych eksporterów lokatę 12. (...) 


\section{WŁADZE SPÓモKI}

\section{ZARZĄD:}

W okresie od 01.01.2000 roku do 21.08.2000 roku skład osobowy Zarzadu Spótki byt nastepujacy:

Józef Mielnikiewicz - Prezes Zarzadu, Grażyna Bula - Wiceprezes Zarzadu, Jerzy Sobczak - Wiceprezes Zarzadu, Krzysztof Sapiński - Członek Zarzadu - Dyrektor Rynku Krajowego. (...)

\section{AKCJONARIAT}

Struktura akcjonariatu na dzień 31 grudnia 2000 roku.

Spółka Akcyjna „PK” z siedzibą w Katowicach, została utworzona 31.01.1996 roku. Spółka wpisana jest do rejestru przedsiębiorców Krajowego Rejestru Sądowego przez Sąd Rejonowy w Katowicach Wydział VIII Gospodarczy Krajowego Rejestru Sądowego, pod numerem KRS 0000116114.

Akcjonariuszami Spółki „PK” w roku sprawozdawczym 2000 byli:

- Jastrzębska Spółka Węglowa S.A. z siedzibą w Jastrzębiu Zdroju - (51,0\% akcji),

- Mittal Steel Poland S.A. z siedzibą w Katowicach - właściciel Zakładów Koksowniczych „Zdzieszowice” Sp. z o.o. w Zdzieszowicach. - (24,5\% akcji),

- Koksownia „Przyjaźń” Sp. z o.o. z siedzibą w Dąbrowie Górniczej - (24,5\% akcji).

\section{PRZEDMIOT DZIAŁALNOŚCI SPÓŁKI:}

W aktualnym Statucie Spółki/wpis do KRS/ zakres działalności Spółki obejmuje prowadzenie działalności handlowej, w tym eksportowo - importowej, usługowej, produkcyjnej na rachunek własny lub w pośrednictwie. Łącznie wymienionych jest 27 wyszczególnień z PKD, jako zakres działalności firmy. Podstawowym przedmiotem działalności Spółki jest realizacja zadań w zakresie sprzedaży hurtowej paliw stałych, ciekłych, gazowych oraz produktów pochodnych. (...)

\section{SYTUACJA FINANSOWA:}

Struktura majątku Spółki jest typowa dla firmy handlowej. Majątek Spółki prawie w całości składa się ze składników obrotowych, gdzie dominują głównie należności krótkoterminowe.

Aktywa ogółem w 2000 roku zmniejszyły się w stosunku do 1999 roku o $47,5 \mathrm{mln}$ zł (o 7,1\%), w tym między innymi zmniejszyły się: należności krótkoterminowe o 7,3\%, tj. o 42,8 mln zł; inwestycje krótkoterminowe o 64,3\%, tj. o 11,7 mln zł; przy wzroście zapasów o 12,1\%, tj. o $6,7 \mathrm{mln}$ zł.

Aktywa trwałe mieszczą się zaledwie w granicach $0,7 \%$ ogólnej sumy bilansowej. Wśród nich dominującą pozycję zajmują inwestycje długoterminowe i długoterminowe rozliczenia międzyokresowe. W 2000 roku zmniejszyły się inwestycje długoterminowe w stosunku do roku poprzedniego o 1,8\%, tj. o 38 tys. zł.

Źródła finansowania majątku w 2000 roku uległy zmniejszeniu o 47,5 mln zł 
(o 7,1\%), głównie wskutek zmniejszenia stanu zobowiązań krótkoterminowych przy wzroście kapitału własnego i rezerw na zobowiązania. Obniżenie stanu zobowiązań, jak i należności krótkoterminowych wynika głównie ze zmniejszenia przychodów ze sprzedaży o 8,7\%. Dominującym składnikiem pasywów Spółki pozostają zobowiązania krótkoterminowe. Jest to zjawisko typowe dla firm pośredniczących w obrocie gospodarczym, w których zarówno aktywa, jak i pasywa wykazują stosunkowo wysoką płynność. Prawie wszystkie zobowiązania mają charakter bieżący i są regulowane terminowo. Ich wielkość jest zbliżona do wielkości należności i w sumie obie te wartości odzwierciedlają wysoki poziom obrotów Spółki. Dodatkowo terminowe płatności zabezpieczane są liniami kredytowymi.

Kapitał własny Spółki na 31 grudnia 2000 roku wyniósł 28.050 tys. zł, w tym: kapitał podstawowy (akcyjny) 4.100 tys. zł, kapitał zapasowy 18.279 tys. zł oraz zysk netto roku obrotowego 5.671 tys. zł. (...)

W roku 2000 w odniesieniu do roku 1999 nastąpiło obniżenie przychodów netto ze sprzedaży o 393,9 mln zł, tj. o 8,7\%. W roku 2000 zwiększył się udział przychodów ze sprzedaży koksu w przychodach ogółem do poziomu 60,4\% (z 52,7\% w roku 1999) przy jednoczesnym zmniejszeniu udziału przychodów ze sprzedaży węgla do poziomu 35,0\% (z 43,5\%). Zauważalną wielkością jest udział w przychodach ze sprzedaży pozostałych asortymentów (głównie przychodów z logistyki materiałowej) na poziomie 4,7\%. Proporcjonalnie do zmian w przychodach ze sprzedaży przebiegają zmiany kosztów sprzedanych produktów, towarów i materiałów.

W 2000 roku Spółka osiągnęła zysk, zarówno ze sprzedaży, jak i na działalności operacyjnej, gospodarczej, brutto i netto, przy ujemnym saldzie przychodów i kosztów finansowych. Osiągnięty przez Spółkę zysk netto 5.671 tys. zł był wynikiem o 5,4 mln zł (o 48,6\%) niższym niż osiągnięty w roku 1999. (...)

Wskaźnik zyskowności aktywów w roku 2000 osiągnął poziom 0,88\%, co oznacza, że każde 1.000,- zł majątku daje 8,80 zł zysku, zaś zyskowność kapitałów własnych na poziomie $22,42 \%$ w roku 2000, mówi, że każde 1.000,- zł kapitału własnego generuje zysk netto w wysokości 224,20 zł. (...)

\section{Appendix 3.}

\section{MT Evaluation Protocol}

\begin{tabular}{|l|l|l|l|l|}
\hline \multicolumn{1}{|c|}{ Type of errors } & \multicolumn{1}{|c|}{ Error specification } & Segment 1 & Segment 2 & Segment ... \\
\hline \multirow{4}{*}{$\begin{array}{l}\text { Grammatical } \\
\text { errors }\end{array}$} & a misspelled word & & & \\
\cline { 2 - 6 } & an incorrect accent & & & \\
\cline { 2 - 6 } & incorrect elision or no elision & & & \\
\cline { 2 - 6 } & incorrect word formation & & & \\
\cline { 2 - 6 } & wrong tense & & & \\
\cline { 2 - 6 } & $\begin{array}{l}\text { the use of a wrong category } \\
\text { of a word }\end{array}$ & & & \\
\hline
\end{tabular}


Joanna Sycz-Opoń, Ksenia Gatuskina

\begin{tabular}{|l|l|l|l|l|}
\hline Type of errors & \multicolumn{1}{|c|}{ Error specification } & Segment 1 & Segment 2 & Segment ... \\
\hline & an incorrect pronoun & & & \\
\cline { 2 - 5 } & incorrect word capitalisation & & & \\
\cline { 2 - 5 } & an incorrect article or no article & & & \\
\cline { 2 - 6 } & missing negative particle & & & \\
\cline { 2 - 6 } & incorrect agreement & & & \\
\hline \multirow{5}{*}{ Syntactic errors } & wrong sentence order & & & \\
\cline { 2 - 6 } & an incorrect conjunction & & & \\
\cline { 2 - 6 } & wrong punctuation & & & \\
\hline Lexico-semantic & mistranslation of a lexical item & & & \\
\cline { 2 - 6 } & no translation & & & \\
\cline { 2 - 6 } & $\begin{array}{l}\text { lack of translator's remark } \\
\text { where necessary }\end{array}$ & & & \\
\hline
\end{tabular}

